\title{
多分割反射電子検出器を搭載した走査電子顕微鏡による結晶粒 形状の評価
}

大塚岳志大竹祐香原昌也 太田康則宮澤聡

日本電子株式会社

J. Japan Inst. Met. Mater. Vol. 84, No. 4 (2020), pp. 135-140

(C) 2020 The Japan Institute of Metals and Materials

Technical Article

\section{Evaluation of Grain Shape of Metals Using SEM with Segmented BSE Detector}

Takeshi Otsuka, Yuka Otake, Masaya Hara, Yasunori Ohta and Satoshi Miyazawa

JEOL Ltd., Akishima 196-8558

Analysis of the particle size of metal specimens is important for quality control of metal alloys. In many cases, the EBSD method was used for grain size analysis. However, the EBSD method requires that the specimen be tilted at a significant angle. Therefore, we tried to observe the grain size using a new detector under non-tilted sample conditions. The detector is a segmented backscattered electron detector that can detect differences in signal intensity due to the EBSD pattern of each segment. The detected signal intensities were compared to obtain the particle shape, and the particle size was measured using this data. [doi:10.2320/jinstmet.JBW201902]

(Received November 7, 2019; Accepted January 17, 2020; Published March 25, 2020)

Keywords: scanning electron microscope, grain size, electron backscatter diffraction pattern

1. 緒言

金属材料の結晶組織は材料強度などの性能に影響するた め, 組織を観察することは材料開発において重要な項目であ る。結晶組織の観察には光学顕微鏡や，走査電子顕微鏡 (SEM) による反射電子像や EBSD (Electron Backscatter Diffraction Pattern) 法 ${ }^{1)}$ が用いられる.

特にSEM ではナノスケールの微細な結晶粒子サイズまで 観察できるので幅広く利用されている。しかし，反射電子像 による結晶粒子の観察ではコントラストの付き方によって結 晶粒子の分類が難しい場合がある。また, EBSD 法では試料 を大きく傾斜するため SEM 像との視野合わせが難しく, SEM 像観察と比較すると取り込み時間が長いなどの課題が ある。

一方, EBSD では試料を約 $70^{\circ}$ 傾斜させた状態で電子線を 入射し EBSD パターンを発生させ，そのパターンを解析す ることで結晶方位を求めているが, 試料を傾斜させなくても EBSD パターンは発生している. しかし，一般的にそのこと は知られておらず，またその条件について明確に示した文献 がない。そこで試料水平で EBSD パターンを取得できる条 件を検討し，その結果を結晶粒子サイズの測定に利用する方 法を検討した。
2. 水平な試料の EBSD パターン取得実験

\section{1 実験方法}

実験の構成を Fig. 1 に示す．EBSD パターンを取得するた め, SEM 対物レンズの下に蛍光板を配置した。蛍光板の中 心には電子線が通過する穴を開けている，蛍光板の蛍光塗料 はプレートの下面に塗られており，試料から放出される電子 を受けて発光する.SEM 試料室の壁面にはビューポートを 設置し, ビューポートの大気側から高感度カメラで蛍光面を 確認できるようにした。試料には金の多結晶を用意し，試料 表面にガラスを押し当てて平坦にした後，バーナーで加熱し てアニール処理した. 試料は通常の SEM 観察と同様に試料 面が水平になるように配置した，次に反射電子像でチャネリ ングコントラストを観察しながら結晶粒形状を確認し, 粒界 から遠い結晶粒の中心付近を照射点に選んだ。そしてその照

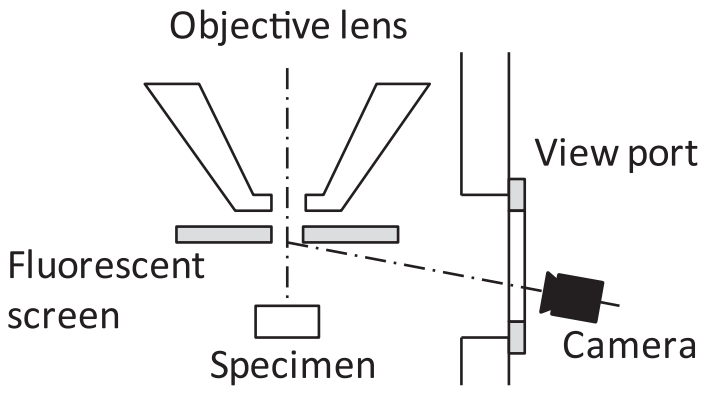

Fig. 1 A schematic diagram of the experiment for obtaining EBSD pattern with non-tilted specimen. 
射点を中心に観察倍率を最大まで上げていき，照射点付近に のみ電子線が当たるようにし，その時の蛍光板像を取得し た．EBSD パターンを取得する際は， EBSD 法と同様にバッ クグラウンドを除去した.

\section{2 実験結果}

取得した蛍光板像の結果を Fig. 2 に示す. (a) は加速電圧 $5 \mathrm{kV}$ のとき, (b) は加速電圧 $10 \mathrm{kV}$ のとき蛍光板像を示 す. カメラの露光時間は $2 \mathrm{~s}$ にした.

加速電圧 $5 \mathrm{kV}$ では EBSD パターンとみられる模様が確認 できた. $10 \mathrm{kV}$ ではうっすら見えるが鮮明ではなかった。

また得られた模様が EBSD パターンか確認するために, EBSD 検出器で同じ結晶粒に対して EBSD パターンを取得し た. 結果を Fig. 3 に示す。（a）は設置した蛍光板で取得した 模様で，（b）はEBSD 検出器で取得した EBSD パターンであ る. Fig. 3(a) は加速電圧 5 kV, Fig. 3(b) は加速電圧 $15 \mathrm{kV}$ で 取得した。電子線の加速電圧が異なるが, 電子のエネルギー は EBSD パターンの太さに影響し，パターン形状そのもの には影響しない2)。Fig. 3(b)の上部に試料水平で取得した模 様と同一の模様を確認することができた．別の方位の異なる 結晶粒に対しても調査し, 同様に EBSD 検出器の上部に蛍 光板と同じパターンを確認した. このことから対物レンズ下 に配置した蛍光板で取得できるパターンは EBSD 検出器で 取得する EBSD パターンと同一のものといえる.

\section{3 考察}

\subsection{1 加速電圧による違いについて}

ここで加速電圧によってパターンの鮮明さが変化した理由
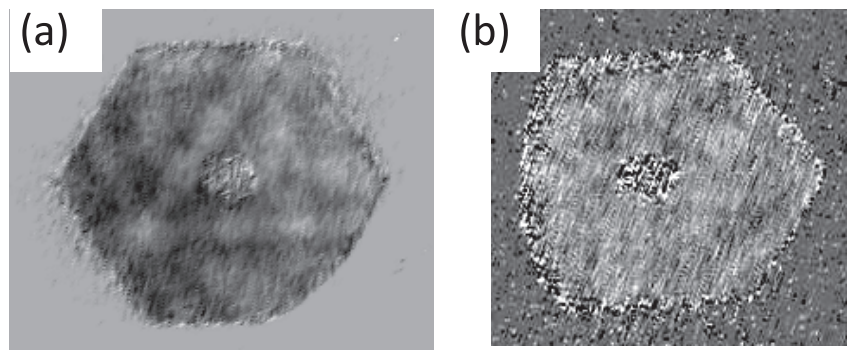

Fig. 2 EBSD patterns from a non-tilt specimen. Accelerate voltage is (a) $5 \mathrm{kV}$ and (b) $10 \mathrm{kV}$.
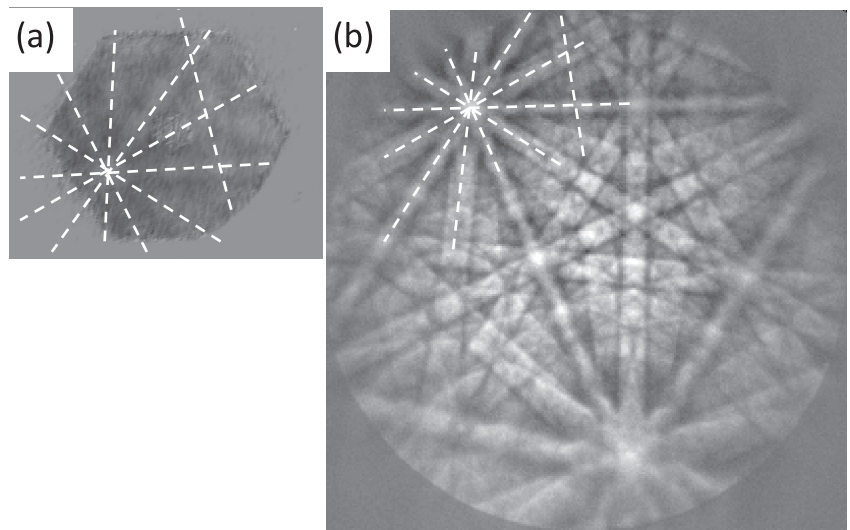

Fig. 3 Confirmed same pattern with EBSD detector. (a) fluorescent screen. (b) EBSD detector.
を考える。

加速電圧によって試料へ入射する電子のエネルギーが変化 する，低エネルギー電子は試料への侵入深さが浅いため, 多 くの入射電子が試料表面付近で散乱し, エネルギー損失が少 ないまま表面から真空中へと脱出する。低加速電圧ではそれ らがパターン形成に寄与したと考えられる。 一方, 高エネル ギー電子は試料に深く侵入し, 試料中でエネルギーを大きく 失うため, それらはパターンの形成には寄与しない3). EBSD 法では比較的高エネルギーの電子を入射しているが, 試料を大きく傾斜させることで電子散乱が試料表面付近で起 こりやすくなっている.

つまり試料表面付近で電子を散乱させることが EBSD パ ターン形成には重要であり, 水平に設置された試料では低加 速電圧にすることでそれを実現している.

2.3.2 水平な試料からの EBSD パターンの利用方法

前項の実験から水平な試料でも低加速電圧であれば SEM の対物レンズ下で EBSD パターンを取得できることが確認 できた。通常 SEMの対物レンズ下には反射電子検出器が配 置されているので, 観察条件によっては反射電子検出器に EBSD パターンが投影されていることになる．このことから 反射電子検出器の位置には結晶に関する情報が来ているとい える。

この位置に EBSD 検出器を配置すれば試料を水平のまま 結晶方位を解析することができるが，一方で蛍光板を撮影す るカメラの露光時間が $2 \mathrm{~s}$ と, パターンを取得するのに長い 時間が必要だった。これは簡単な実験構成だったことを考慮 しても取得時間としては長く, 方位マップのような広範囲で パターンを取得して解析するような用途には向かないと考え る.そこで EBSD パターンを画像として取得するのではな く, 検出面が分割されたセグメント型の多分割反射電子検出 器(以下, 多分割検出器)を用いて, EBSD パターンを反映し た信号強度分布を取得することで結晶に関する情報の取得を 試みた。多分割検出器であれば， 1 セグメント当たりの検出 立体角が大きくなるので短時間で高 SN 比の信号が得られ る.

\section{3. 多分割検出器を用いた結晶情報の取得}

\section{1 実験方法}

\subsection{1 多分割検出器}

多分割反射電子検出器として Fig. 4 のような 16 個のセグ メントに分割された検出器を用意した。検出器としては通常 のフォトダイオードと同様で, 入射した電子がダイオード構

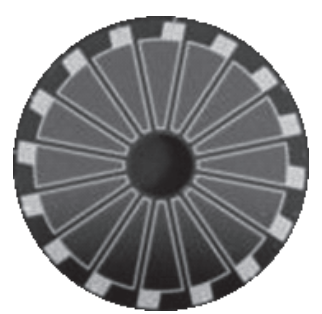

Fig. 4 An image of 16 segmented back-scattered electron detectors (BEDs). 
造でキャリアを発生させ，それらは電流信号として出力され る.

\subsection{2 データ取得方法}

多分割検出器から出力された電流信号は IV アンプによっ て電圧信号に変換・増幅されたのち $\mathrm{AD}$ 変換されて 16 個の 信号が同時にコンピュータに取り込まれる.

多分割検出器信号の取り达みは，通常の SEM と同様に 1 次電子の走査と同期して行う。本検出器の場合, 走査方向に 沿った座標位置に対して 16 個の信号值が取得できる。ここ で座標 $[x, y]$ におけるセグメント $i て ゙$ 取得した信号を $D[x, y, i]$ とする.

それぞれのセグメント $i$ の信号に対して SEM 像を作成す れば 16 枚の SEM 像が得られる。例として金の多結晶を試 料とし, 16 分割検出器でデータ取得して, $i=3, i=4$ に対 するSEM像を作成した。結果を Fig. 5 に示す。これらを見 比べるとコントラストの異なった画像が得られている。よく 観察すると，一方では明確に区別できる粒界が他方では見え づらいところが見られる。このような違いは EBSD パター ンに起因するものであり，これを利用すれば結晶の情報が多 分割反射電子検出器で取得できると考えられる.

\subsection{3 データ処理方法}

取得したデータから結晶に関する情報の抽出方法を考え る. ここで, 座標 $[x, y]$ での検出器ごとの信号 $D[x, y, 1]$, $D[x, y, 2], \cdots D[x, y, 16]$ をその点での信号強度分布とする. この信号強度分布は EBSD パターンから成るものなので, 理論的には同一の結晶方位で同じ分布になる。実際には 1 次 電子の走査によって EBSD パターンの発生点が移動し，そ れによるパターンの僅かな変化や，ノイズの影響があるので 全く同じにはならない．そこで信号強度分布の近似性を評価 することで同一の結晶方位かどうか判断することにした.

近似性はユークリッド距離4) を用いて次のように評価し た. 取得したデータの中から比較基準となる座標 $\left[x_{b}, y_{b}\right]$ (点 B）を設定し，その点での信号強度を $D\left[x_{b}, y_{b}, i\right]$ とした。 $\left[x_{b}, y_{b}\right]$ の強度分布と各座標点 $[x, y]$ に拈ける信号強度分布を 比較し, 近似性が高いものを同一の結晶方位と判断する.

近似性評価には次の式を使った。ここでの $n$ は検出器セグ メント数の 16 となる

$$
E d[x, y]=\sqrt{\sum_{i=1}^{n}\left(D\left[x_{b}, y_{b}, i\right]-D[x, y, i]\right)^{2}}
$$

比較する 2 点間で近似性が高いと $E d[x, y]$ の值は小さくな

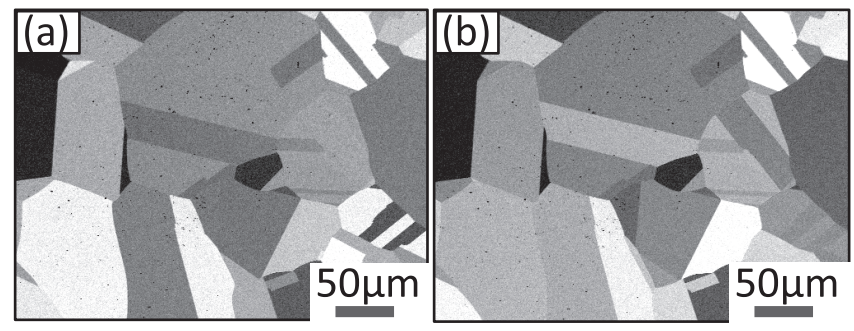

Fig. 5 SEM images of polycrystalline gold acquired using segmented BED signals. Image (a) is acquired by segment 3 and image (b) by segment 4 . Some grain boundaries are visible in one image but not in the other.
る

式（1 ）を使って各座標における近似性を評価し，得られた $E d[x, y]$ を明るさとした画像を作成した。得られた画像では, 基準点 $\mathrm{B}$ と強度分布が似ている領域, つまり基準点 $\left[x_{b}, y_{b}\right]$ と同一の結晶方位が暗く示され，それ以外の異なる結晶方位 では $E d[x, y]$ に対応した明るさで示される．取得した画像の ヒストグラムをとるといくつかのピークが得られ，その中で 最も暗い側にあるピークに相当する領域が基準点 $\mathrm{B}$ と同一 の結晶方位と判断できる.

\section{2 実験結果}

式（1）を使って作成した像を Fig. 6 に示す。ここでは Fig. 6 中の矢印の点を基準点 $\left[x_{b}, y_{b}\right]$ とした．試料には金の多結晶 を使った。

$\left[x_{b}, y_{b}\right]$ を内包する結晶粒が暗くなっており, 結晶粒形状が 明確になり，結晶粒形状の取得に有効であった。また，それ 以外の結晶粒においても同じ暗さの領域が見られた。これら についても同一の結晶方位である可能性が高い.

そこで Fig. 6 と同一視野の IPF(Inverse Pole Figure) マップ を取得した(Fig. 7)。ここで通常のIPFマップでは，反転対 称の結晶方位は同じ方位として表示するが, 本検出器で取得 した場合これらは異なる強度分布となるので, Fig. 7 は反転

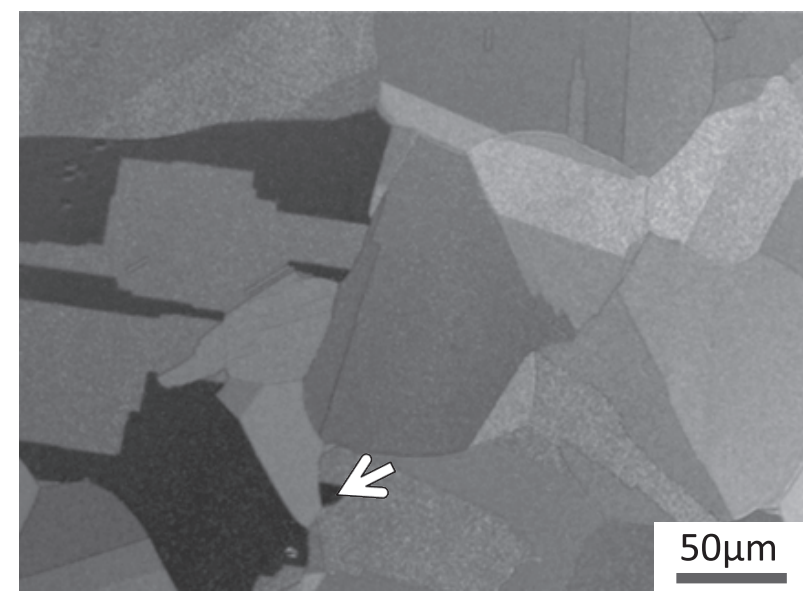

Fig. 6 SEM image with contrast modified by Eq. (1). The base point $\mathrm{B}$ is indicated by a white arrow.

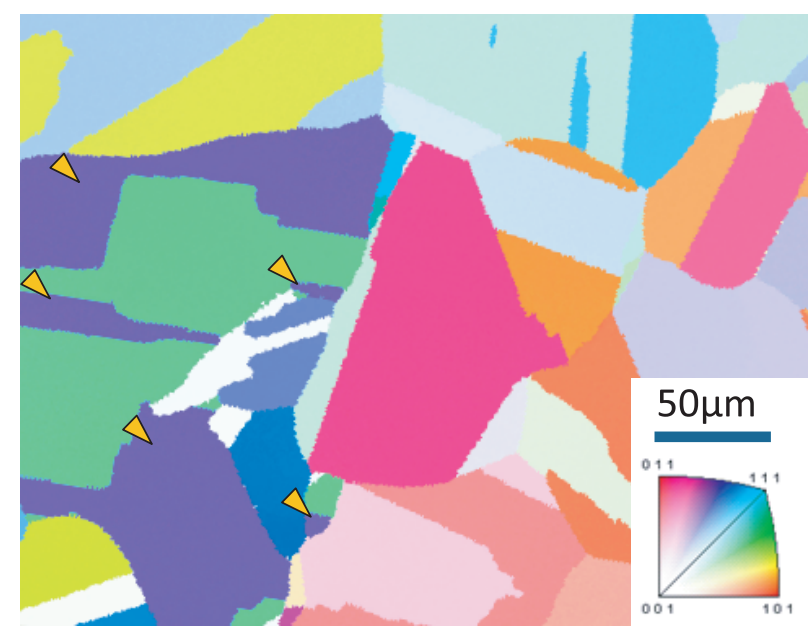

Fig. 7 IPF map of the same field of view as in Fig. 5. 
対称の結晶を異なる色で表示するマップとなっている.

三角で示した領域は Fig. 6 で暗く表示されている領域であ り,これらはすべて同じ結晶方位であった。このことから 16 分割検出器で取得した強度分布が結晶性の情報を有して いることが示された.

次に式 ( 1 )を使って検出できる結晶方位差について検証し た. EBSD で粒内に僅かな方位角度変化のある領域を探して 方位解析し, 同領域を多分割検出器でデー夕取得した。 その 後取得したデータからラインプロファイルを作成し，ライン プロファイルの始点を基準点として EBSD は基準点との結 晶方位差, 分割検出器は基準点との強度分布のユークリッド 距離を求め, グラフにプロットし比較した.

その結果を Fig. 8 に示す. グラフを見ると方位差が $0.5^{\circ}$ に なる辺りからユークリッド距離は大きくなり, 方位差が $1.5^{\circ}$ を下回る辺りでユークリッド距離が再び小さくなった.

この結果では本方式の方位角度分解能は $0.5^{\circ}-1.5^{\circ}$ 程度と みられるが, 本稿ではこの結果を本方式における角度分解能 の参考值として示すだけに留めたい. 正確に求めるためには さらなる検証が必要と考え, その理由は次の節で述べる.

\section{3 考察}

前節の結果から, 16 分割検出器で取得した信号を使って 結晶粒形状や, 同一の結晶方位が判断でき, 結晶の情報を取 得できることを確認した. 一方で角度分解能についてはさら なる検証が必要とした。 その理由について述べる。

本方式では, 多分割検出器に投影された EBSD パターン を，各受光面の形状で積分した信号として取得している.

Fig. 9 にそのイメージ図を示す.ここで Fig. 9(a)の EBSD パターンに対して, Fig. 9(b), Fig. 9(c)は同じ方位差で異な

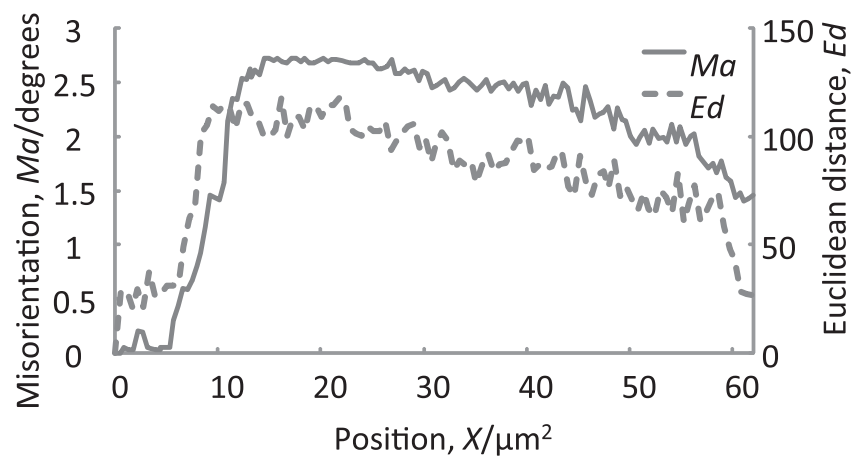

Fig. 8 Lineprofile of misorientation and Euclidean distance.

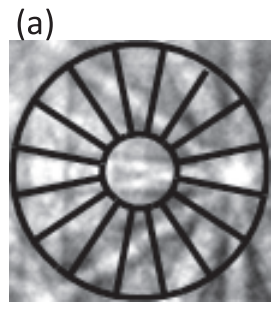

(b)

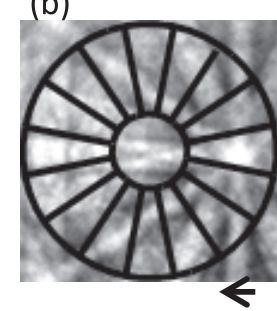

(c)

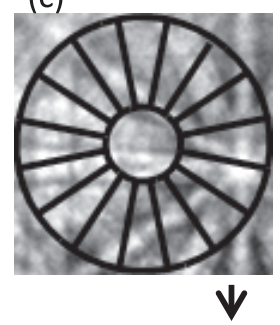

Fig. 9 Illustration of EBSD pattern on the segmented BED. (a) Comparison source. (b) and (c) are same misorientation as (a), but they are inclined in different directions.
る方向に傾いた結晶による EBSD パターンを考える. EBSD パターンと検出器形状の関係をよく見ると, Fig. 9(a)で右側 にある輝点に対し, Fig. 9(b) は輝点が同一の受光面内で移動 している. 一方で, Fig. 9(c) は輝点が異なる受光面へ移動し ている.

そのため多分割検出器から出力される信号の強度分布は, Fig. 9(b)はFig. 9(a)に対して変化量が小さく, Fig. 9(c)は Fig. 9(a)に対して変化量が大きい. 実際に Fig. 9 の画像を 使って, 受光面で囲まれた領域の輝度を積分し，それを検出 信号としてユークリッド距離を計算すると, Fig. 9(a) と Fig. 9(b)のユークリッド距離を 1 としたとき, Fig. 9(a)と Fig. 9 (c)のユークリッド距離は 1.65 となった．方位差ではほぼ同 じにもかかわらず類似性の評価值としては大きく異なる值と なる。

このように本方式で得られるユークリッド距離は方位差に は依存しない。 そのため, 簡単な評価で角度分解能を示すこ とはできないと考える。また投影される EBSD パターンに よって, 本来は異なる結晶方位であっても類似性の高い強度 分布になりうる.

角度分解能を示すためには, EBSD によって結晶方位を解 析し, 同じ位置を多分割検出器による信号を取得し, それを 様々な結晶方位に対して行って統計的に求めることが必要と 考える. しかし傾斜して取得したデー夕に合わせて正確に位 置合わせしてデータを取ることが難しく，また大量のデータ を取得して比較しなければならない, そのため, 詳細な角度 分解能の評価は今後の課題とする.

このように現段階では角度分解能についてさらなる検討が 必要であるが, 参考值として得られたデータでは比較的小さ い角度変化を検出できることを確認できた。 そこで EBSD パターンに基づいた正確な結晶粒方位を求める必要はない が，短時間で結晶粒子サイズを計測する結晶粒計測ツールと しての利用を考えた。

\section{4. 多分割検出器を用いた結晶粒子サイズの計測実験}

\section{1 実験方法}

結晶粒計測ツールとして利用するには，粒界を求めそこか ら粒度分布や粒径分布を計算する。そこで粒界を抽出するた めの処理が必要となる。

粒界は 2 つ上の異なる結晶方位の結晶粒の間の境界であ る. 多分割検出器では小さな角度変化でも検出可能なので, 取得したデー夕から隣接する点同士で強度分布を比較し，そ れらが似ていなければその 2 点は異なる結晶方位であり，2 点の間には粒界が存在するということになる.

そこで粒界の判定には次のような式で判定を行った.

$$
\begin{aligned}
& B d[x, y]= \sqrt{\sum_{i=1}^{n}(D[x, y, i]-D[x-1, y, i])^{2}} \\
&+\sqrt{\sum_{i=1}^{n}(D[x, y, i]-D[x, y-1, i])^{2}}
\end{aligned}
$$

ここで， $B d$ が閾值以上なら粒界と判断する. 閾值の設定 は, 試料の状態やSEM の観察条件によっても変化するの 
で，取得した信号に対し闇值を変化させながらその時の粒界 像を確認し，最適な条件になるよう調節した。

電子線をスキャンしながら表示することを考慮すると，こ の式を計算するのに必要な值は，スキャン方向に対して，す でに取得した座標のみで計算できるので，スキャンしながら $B d[x, y]$ を表示することが可能となる.

式 (2)では測定点 $[x, y]$ と, $[x-1, y]$ と $[x, y-1]$ の 2 点で 比較しているが，実際の信号では比較する点を増やし，広範 囲の点との比較をすることで判定の精度を上げた。

\section{2 実験結果}

取得した粒界像を Fig. 10(a)に，同視野の組成像を Fig. 10 （b）に示す. Fig. 10（a）の矢印で示した粒界は組成像からでは 確認できない粒界である。

粒界像が取得できたので，この像を使えば結晶粒子サイズ の計測が行える. Fig. 11 に ImageJ ${ }^{5,6)}$ を使って結晶粒子サイ ズを測定した例を示す。

さらにこの方法で得られた結晶粒子サイズと, EBSDに よって測定したサイズを比較した。今回多分割検出器で取得 した粒界像は，粒界抽出の精度を上げるために式 ( 2 )より比 較点数を多くしているが，それによって抽出される粒界が実

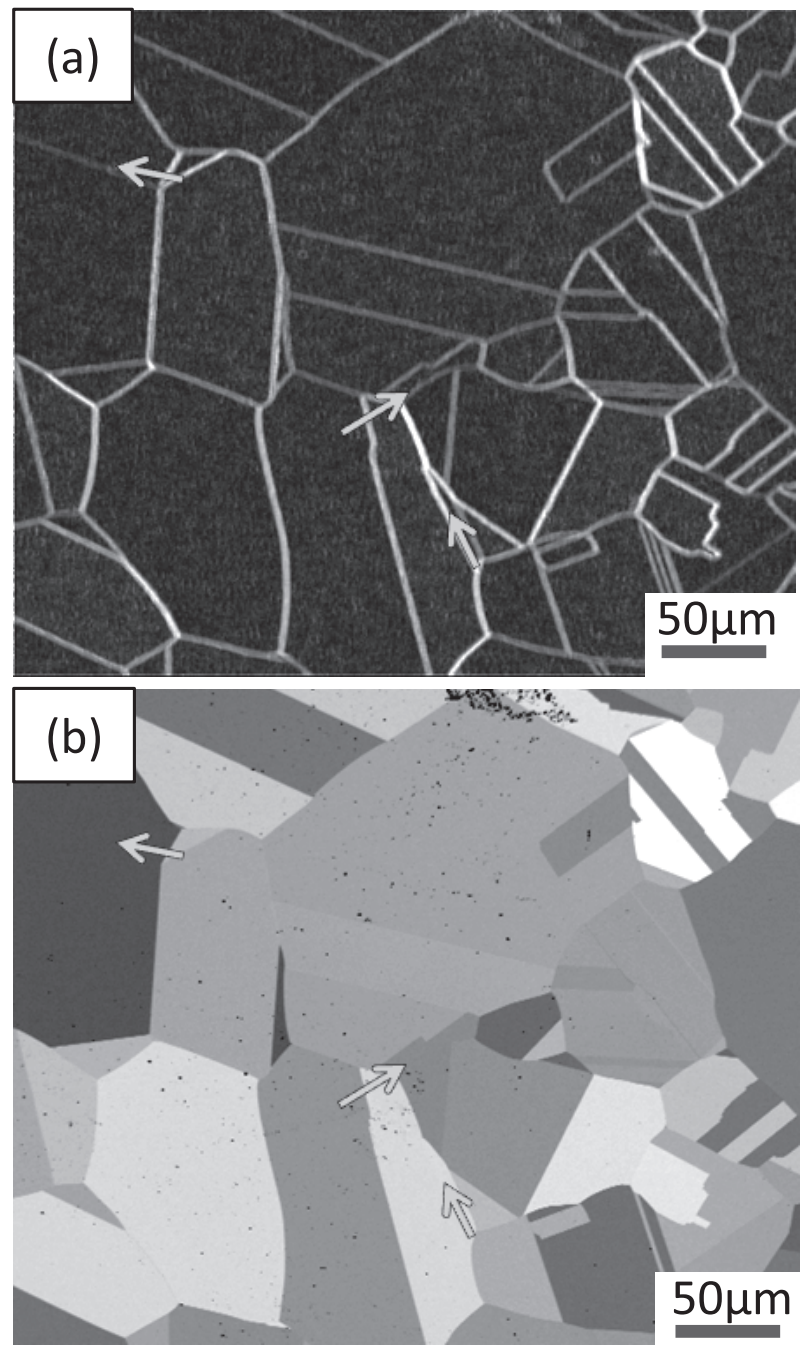

Fig. 10 (a) Image of grain boundaries extracted. (b) Composition image with the same field of view as in (a).
際より太くなるため，結晶粒子サイズとしては小さくなって しまう。そこで抽出された粒界像の粒界を細線化し，その結 果を用いて粒の面積を測定した。また現時点では多分割検出 器で取得した像に対し，スケールの保証はできていない。そ のため, EBSD で取得した結晶粒のうち視野中心付近にある 1 つの結晶粒を使って本方式の測定サイズを補正し，その後 はそれぞれの測定方法で結晶粒子サイズを求めて比較した。

測定した結晶粒子サイズの比較結果を Fig. 12 に示す。Fig. 12 の横軸は EBSD で計測した結晶粒の面積，縦軸は多分割 検出器で取得し求めた面積で，それぞれが対応するサイズの 点にプロットした．補正に使ったサイズは Fig. 12 中の矢印 で示している。10 個の結晶粒について比較し，最小で約 $0.1 \%$ ，最大で約 $10 \%$ のずれがあった

このデータを取得するために要した時間は, EBSD では電 子線照射点数が 43478 点で約 $11 \mathrm{~min}, 16$ 分割検出器では電 子線照射点数 804452 点で約 1 min だった.

\section{3 考察}

前節の実験結果から，EBSD と比較して短時間で結晶粒形 状が取得できることから，広範囲で結晶粒子サイズを取得し たい場合に有効と考えられる.

また，試料を水平のまま取得できることから，通常の SEM 観察で使われる検出器と同時に取得できる。例えば SEM 用の EDS 検出器と同時に使って, 試料を加熱しながら 析出物の分析と結晶粒形状の取得を行い, 結晶粒の微細化や 粗大化に対する添加元素の影響を調査するのに有効になるの ではないかと考えられる。そのため熱処理中の結晶粒の粗大

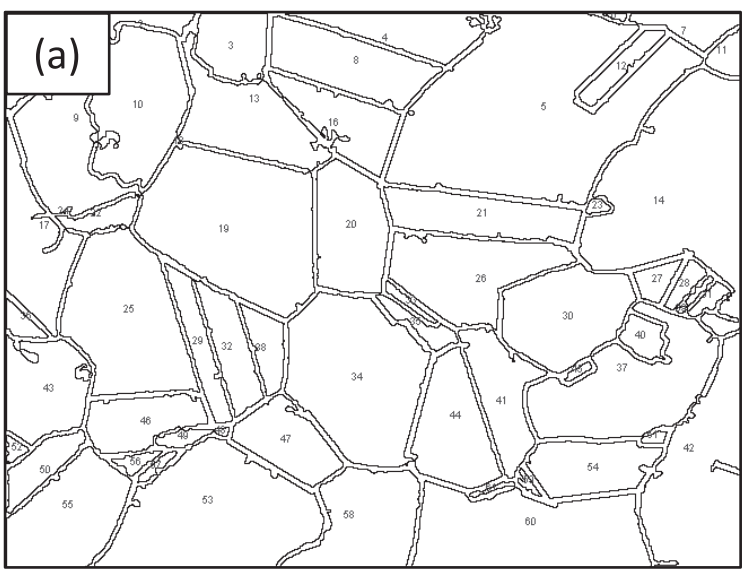

(b)

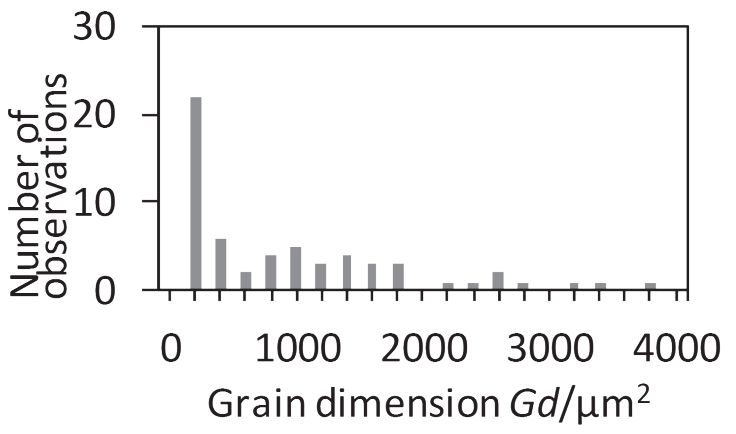

Fig. 11 Grain size analysis of polycrystalline gold. (a) Numbering of grains. (b) Distribution of grain dimension. 


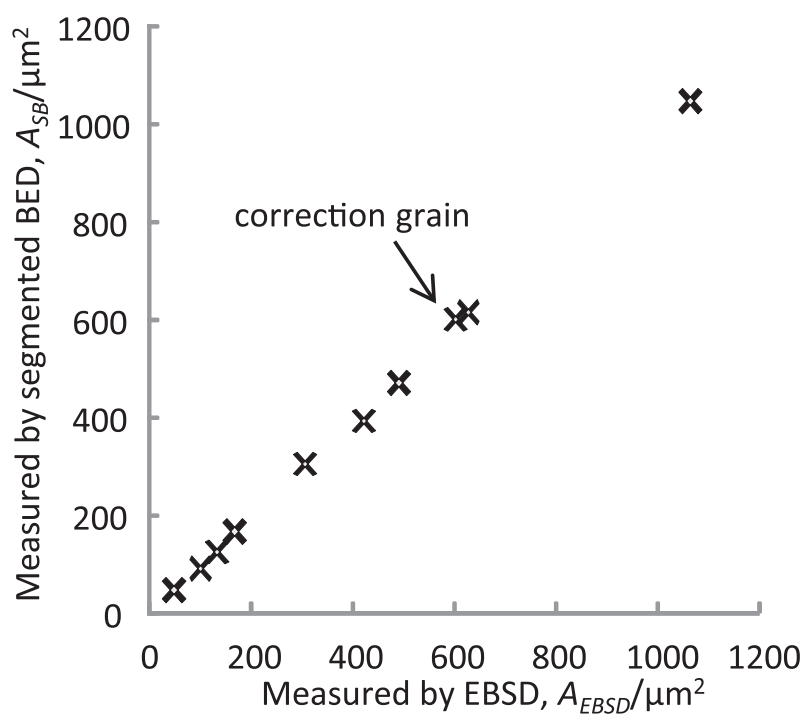

Fig. 12 Difference of grain size by each measurement method.

化や微細化のプロセスを観察するのに有効なツールになると 期待される。

次に結晶粒子サイズの精度について考えるＥBSD と本方 式で測定した結晶粒子サイズの間には最大約 $10 \%$ 差が あった. EBSD は試料を傾斜して取得したデータなので, 結 晶粒子サイズを求めるためには傾斜の補正が必要だが，計算 に適用する傾斜角と実際の傾斜角の間に僅かなズレがある と, サイズを求める際に誤差となってしまう。本方式は試料 水平のまま取得しているためそういった誤差は少ないと考え る。一方で多分割検出器によって取得した粒界は, 結晶方位 に基づいた判定ではなく，信号強度の違いを利用し，さらに 画像処理で抽出しているので, 実際の粒界とは違う領域を粒 界と判断してしまうおそれがある。そのためどちらも実際の 值からのズレを含んでいる可能性があり, 結晶粒径の精度に
関して優位性の判断は難しい.しかし，測定結果の傾向とし て，本方式は EBSD による結晶粒子サイズ測定とは大きく 乘離していない。そのため試料水平のまま, 短時間で取得で きる特徵を生かし，例えば試料ステージを移動させながら広 範囲で粒度分布を測定するといった用途で有効になると考え る. また多分割検出器では比較的低加速電圧の電子線で取得 するので，近年の低加速電圧で高分解能の SEM を用いるこ とで微少サイズの結晶粒測定も可能になると考える。

多分割検出器による粒界抽出の精度検証については, 処理 方法を含めて今後の課題とする.

\section{5. 結 論}

走査電子顕微鏡で, 水平に配置した結晶性の試料に数 $\mathrm{kV}$ の比較的低い加速電圧の電子線を照射して, 発生した EBSD パターンを検出できることを確認した.

この $\mathrm{EBSD}$ パターンを多分割の反射電子検出器を使って 各電子線位置での信号強度分布として取得し，その強度分布 を比較することで結晶粒形状や粒界の情報を得ることができ た。これにより短時間で結晶粒子サイズを取得できるように なり, 金属材料の品質検査や, 結晶組織のその場観察に有効 に利用できると期待される。

文献

1) S. Suzuki: Materia Japan 40(2001) 612-616.

2) S. Suzuki: J. Japan Inst. Met. Mater. 77 (2013) 268-275.

3) S. Suzuki: KENBIKYO 39(2004) 121-124.

4) M.M. Deza and E. Deza: Encyclopedia of Distances, (Springer Nature, Berlin, 2009) p. 94.

5) C.A. Schneider, W.S. Rasband and K.W. Eliceiri: Nat. Methods 9 (2012) 671-675.

6) W.S. Rasband: ImageJ, U.S. National Institutes of Health. https://imagej.nih.gov/ij/, (accessed 2019-10-29). 